\title{
A FULLY ONLINE COURSE EXPERIENCE FROM STUDENTS' PERSPECTIVE: READINESS, ATTITUDES AND THOUGHTS
}

\author{
Dr. Emine CABI \\ ORCID:0000-0002-7488-0309 \\ Faculty of Education, Baskent University \\ Ankara, Turkey \\ Dr. Filiz KALELIOGLU \\ ORCID: 0000-0002-7729-5674 \\ Faculty of Education, Baskent University \\ Ankara, Turkey
}

Received: 27/03/2018 Accepted: 18/02/2019

\begin{abstract}
The purpose of the study was to reveal the effect of a course taken through distance education on students' readiness and attitudes. Sequential explanatory design method was used as a research method in which qualitative and quantitative measurements were used in the research. For the quantitative data, a single group pre-test/post-test design was used as an experimental model; for the qualitative data, open-ended questions were asked in order to elicit students' opinions following the experimental process. The study group consisted of 266 students from different faculties and departments who were studying undergraduate and associate degree programmes at a private university in Turkey. Results indicated that the course taken through distance education had a significant effect on students' gaining Computer and Internet SelfEfficacy and was effective in improving undergraduate students' self-directed learning skills. Moreover, the course taken through distance education had a significant effect on students' familiarity with e-learning. Additionally, the course was found to be effective in decreasing the escape attitudes from e-learning.
\end{abstract}

Keywords: e-Learning, distance education, e-readiness, attitude.

\section{INTRODUCTION}

The use of ICT is becoming more and more important within the modern educational process, and there have been many questions raised concerning its efficacy. Classical forms of education are augmented by the modern computer, mediated communication and education, as well as with new forms of organisational change, funding, and changing attitudes towards ICT. Attitudes amongst undergraduate students towards effective learning environments play an important part in their higher education (HE). An effective learning atmosphere is a flexible arrangement of elements that affects student learning success for all stakeholders such as learners, faculty members or professional staff (Appatova \& Prats, 2007). It could be said that the learning process is actually influenced by the environment in which the technology is used. The presence of learning supported in this environment may be associated with many variables. Learning management systems used in the e-learning process serve as an opportunity to prepare the ground for learning. In support of this, there are a number of theoretical models that have been suggested to assist in the understanding of factors impacting the acceptance of these information technologies. The Unified Theory of Acceptance and Use of Technology (UTAUT) model, developed by Venkatesh, Morris, Davis, and Davis (2003), attempted to explain how individual preferences influence technology usage in terms of perceived usefulness, ease of use, and intention to use. This model not only underscores the individual differences on technology usage and acceptance, but also determines the probability of reducing and increasing the effects of these variables. According to the model, performance expectancy, effort expectancy, and social influence were hypothesised and discovered 'to influence behavioral intention to use a technology, while behavioral intention and facilitating conditions 
determine technology use' (Venkatesh, Thong, \& Xu, 2016, p. 329). Marchewka, Liu, and Kostiwa (2007) analysed the effect of Blackboard usage from the UTAUT model perspective and reported that students had positive attitudes toward using Blackboard, that using Blackboard was deemed a good idea, and that they liked working with it. Another study focusing on UTAUT, by Yoo, Han, and Huang (2012), aimed to uncover the motivational effects on employees' purpose of using e-learning in the office. They theorised that variables such as performance expectancy, social impacts, and enabling circumstances were factors of extrinsic motivation, whilst effort expectancy was a factor of intrinsic motivation.

Allport (1935) named an attitude as a 'mental or neural state of readiness, organized through experience, exerting a directive or dynamic influence on the individual's response to all objects and situations to which it is related' (p. 810). Another definition states 'attitude is a psychological tendency that is expressed by evaluating a particular entity with some degree of favour or disfavour' (Eagly \& Chaiken, 1993, p. 1). Fishbein and Ajzen (1977) stated that attitudes can explain people's intentions towards behaviour, and that intention is also a direct predictor of behaviour. When the literature about learners' attitudes for online learning are examined, according to a study by Ozgur and Tosun (2010), it was emphasised that no significant effect was found on the e-learning Attitudes of the Internet Experience in research conducted with experimental and control groups at the beginning and end of a 14-week Internet-supported course. In a similar study, the effects of web-based active learning applications on teacher attitudes towards courses were investigated (Arikan, 2006). In the experimental design study, web-based learning applications positively affected attitudes towards the lesson. Tekinarslan (2009) reported that students who had used the Web for nine common Web activities indicated significantly more positive attitudes toward the Web on most subscales. Moreover, the students with higher Web experience in terms of frequency of usage had higher attitudes on all subscales. Also, the findings indicated that PC-owning students, who were therefore more likely to frequently use the Internet (e.g., daily), had significantly higher attitudes on the usefulness, selfefficacy, and affective subscales than non-PC-owners.

Zabadi and Al-Alawi (2016) conducted a study to examine students' attitudes towards e-learning. The study examined the impacts of gender, technology usage, and skills on students' attitude towards e-learning. Their analysis provided strong support for three null hypotheses. In addition, the study found the influence of gender, technology usage, and skills to be statistically significant, with students having generally positive attitudes towards e-learning. Consequentially, the researchers concluded with a high degree of confidence that university students are willing to accept many courses via the online medium. Despite the fact that students consider an effective learning environment to be very important, student self-motivation is also equally important (Fabac, Vidacek-Hains, \& Pazur, 2011). In their study, Sun and Chen (2016) reviewed 47 studies and research on online teaching and learning published since 2008, primarily focusing on how theories, practices and assessments are applicable to the online learning environment. Based on their findings, the authors argued that effective online instruction is dependent upon well-designed course content; motivated interaction between the instructor and learners; well-prepared and fully-supported instructors; creation of a sense of online learning community; and the rapid advancement of technology.

When the literature about learner readiness for online learning is examined, it can be seen that readiness is a key factor for online learning. Hao (2016) conducted a research study that resulted in numerous implications of students having much lower readiness levels for previews and in-class communication self-efficacy than for other readiness dimensions; both the associated and cause-effect relationships of readiness levels and language beliefs indicate that improving students' language beliefs is essential if the adoption of flipped learning is to be successful, and lastly teachers need to convince students of their proficiency, competency, and show empathy with their students to order to increase readiness levels. Parkes, Stein, and Reading (2015) conducted a study to assess the level of preparedness of students for a range of e-learning competencies described in behaviour-specific terms. Their results showed that students were considered unprepared for a range of e-learning competencies; in particular, time management, critical thinking skills, and collaboration with others. According to Engin's (2017) study, there was a significant relationship between the levels of learners' readiness for online learning and levels of emotional intelligence. The results revealed that students did not feel ready in terms of time management, critical thinking skills, or collaboration with others.

With regards to learner readiness for online learning, Ilgaz and Gulbahar (2015) conducted a study to explore participants' readiness and expectations at the beginning, and their satisfaction levels at the end, 
of an online learning experience. Quantitative analysis showed that online learners placed more emphasis on factors affecting success, with access to technology and ICT competencies perceived as individual characteristics as a whole. Results from the qualitative data showed that they had an expectation of being able to address the deficiency of not being able to attend formal education due to their individual responsibilities. Based on this, it is observed that access type (to education) supports the interaction and thereby creates an expectation. In a study conducted by Ozturk, Ozturk, and Ozen (2018) to determine the effects of levels of readiness and satisfaction of students with online learning experiences, the level of teacher candidates' readiness and satisfaction from web-based distance education were found to be above average. Cole, Shelley, and Swartz (2014) conducted a series of surveys over eight academic terms. There were no statistically significant differences found in the level of satisfaction based on gender, age, or level of study. Overall, the students rated their online instruction as moderately satisfactory, with hybrid or partially online courses rated as somewhat more satisfactory than fully online courses. 'Convenience' was the most cited reason for satisfaction, whilst 'lack of interaction' was the most cited reason for dissatisfaction. Topal (2016) determined the relationship between e-course satisfaction and online learning readiness by ascertaining student levels, and the effect of materials used in e-learning on student satisfaction. There was no significant difference found in the students' satisfaction with exams and homework as assessment tools, or the content of textbased documents (including Portable Document Format or .pdf) as content tools. However, text-based documents and exams were among the most used tools in the courses. Student satisfaction was high when the number of materials used in courses was seven or more; that is, as the number of materials increased, so did the students' satisfaction level. The levels of student readiness for online learning were high in all subdimensions, and there was a positive significant relationship between students' levels of readiness and their satisfaction level. Moreover, the satisfaction levels of learners who were self-directed, had high motivation and could control their own learning appeared to be affected positively.

Considering the relationship of online learning readiness with other variables, Horzum, Kaymak, and Gungoren (2015) found that students' online learning readiness levels directly predicted their academic motivation and indirectly predicted their perceived learning. It was also found that student academic motivation directly predicted their perceived learning. The proposed model was verified in accordance with data obtained from the research. Using the model, Horzum et al. (2015) determined that academic motivation is effective in increasing perceived learning in online learning, and that increasing readiness is an effective way to increase academic motivation. Similarly, Jena (2016) conducted a study to find the interrelationship of student attitude, readiness, and learning style towards the effective use of Virtual Learning Environments (VLEs), and revealed a correlation among learning readiness, attitude, and learning style, with each factor influencing the effective use of the VLE.

To summarise, in order to increase student motivation and satisfaction within the e-learning process, the important factors are considered to be the interaction between teachers and students (Cole et al., 2014; Ilgaz \& Gulbahar, 2015; Sun \& Chen, 2016; Parkes et al., 2015), course content with well-designed and rich materials (Ilgaz \& Gulbahar, 2015; Sun \& Chen, 2016), and the level of readiness to learn online (Hao, 2016; Horzum et al., 2015; Parkes et al., 2015; Topal, 2016). On the other hand, some research studies have shown no meaningful effect of attitude towards e-learning (e.g., Ozgur \& Tosun, 2010), whilst other studies showed attitude towards e-learning as positively influencing active participation in e-learning applications (Aixia \& Wang, 2011; Rhema \& Miliszewska, 2014; Zhu, 2012). Overall, e-learning attitude has been shown to influence the acceptance of online courses (Zabadi \& Al-Alawi, 2016), and the use of web-based learning practices (Arikan, 2006; Tekinarslan, 2009).

According to the literature review, it is clear that students' readiness level, attitudes, and satisfaction are important variables that affect distance learning. Therefore, the current study aims to answer the following research questions.

For students who take courses via distance education;

1. Do the readiness levels of online learning learners change significantly through distance education?

2. Do the attitudes towards e-learning of students taking courses through distance education change significantly?

3. What are the thoughts of students taking courses through distance education? 


\section{METHOD}

Sequential Explanatory Design method was utilised as the research method for the current study, in which qualitative and quantitative measurements were both employed in the research. According to Johnson and Onwuegbuzie (2004), the researcher can answer research questions in a broader and more complete way, since the research is not limited to one single method. It is also necessary to reveal more descriptive details of the general state of the qualitative data, while the quantitative data research problem gives a general outcome (Creswell, 2012, p. 542). For the quantitative data, a single group pre-test/post-test design was used as an experimental model; whilst for the qualitative data, open-ended questions were asked in order to elicit opinions from the students after the experimental process (Table 1).

Table 1. Design of the study

\begin{tabular}{lll}
\hline Pre-test & $\begin{array}{l}\text { Treatment } \\
(14 \text { weeks })\end{array}$ & Post-test \\
\hline $\begin{array}{l}\text { Readiness for Online Learning Scale } \\
\text { Attitude Scale for e-Learning }\end{array}$ & $\begin{array}{l}\text { Activities via distance } \\
\text { education }\end{array}$ & $\begin{array}{l}\text { Readiness for Online Learning Scale } \\
\text { Attitude Scale for e-Learning } \\
\text { Open-ended questions }\end{array}$ \\
\hline
\end{tabular}

Students in the study group received Computer Literacy (CL) lessons though distance learning over a duration of 14 weeks. The CL course is a university-wide compulsory course, with the exception of the Faculty of Engineering, and designed with consideration of the learning environments required for distance education. The course has been conducted through distance education for the past three semesters.

The course was conducted through Moodle ${ }^{\mathrm{TM}}$, which is a learning management system (LMS) used by both instructors and trainees. Presentations summarising each subject, documents giving detailed narration (course notes), source videos, and measurement-evaluation activities all took place offline within the LMS learning environment. In the online learning environment, synchronous (live) lessons were held with videobased lectures each week for one lesson hour and then the course was shared via the registration system. The course was based on the basic module and standard module of the European Computer Driving License (ECDL Foundation, 2017), which was renewed after 2013 with regard to changes in society and technology.

\section{Participants}

The study group consisted of 266 students from different faculties and departments who were studying undergraduate and associate degree programmes at a private university in Turkey. A total of 402 students participated in the pre-test, and 574 students participated in the post-test. As a result of the online questionnaire forms, data from 266 students involved in both the pre-test and post-test were analysed within the scope of this study. Of the study group participants, $75.9 \%(n=202)$ were female and $24.1 \%(n=64)$ were male. Moreover, $4.9 \%(n=13)$ were attending a preparatory class, $84.6 \%(n=225)$ were first-year students, $7.5 \%(n=20)$ were second-years, and 3.1\% $(n=8)$ were attending other years (see Table 2$)$.

Table 2. Demographic features of the Study Group

\begin{tabular}{|c|c|c|c|}
\hline & & $f$ & $\%$ \\
\hline \multirow[t]{3}{*}{ Gender } & Female & 202 & 75.9 \\
\hline & Male & 64 & 24.1 \\
\hline & Total & 266 & 100 \\
\hline \multirow[t]{5}{*}{ Grade } & Preparatory class & 13 & 4.9 \\
\hline & $1^{\text {st }}$ year & 225 & 84.6 \\
\hline & $2^{\text {nd }}$ year & 20 & 7.5 \\
\hline & Other years & 8 & 3.1 \\
\hline & Total & 266 & 100 \\
\hline
\end{tabular}




\section{Data Collection Tools}

\section{Learners' Readiness Towards Online Learning (LROL)}

The Readiness for Online Learning Scale was originally developed by Hung, Chou, Chen, and Own (2010). The adaptation of the scale to Turkish and its validity and reliability studies were performed by Yurdugul and Alsancak Sarikaya (2013). The scale is formulated as a five-point, Likert-type instrument, consisting of 18 items in five different factors.

Within the scope of the current study, Explanatory Factor Analysis (EFA) was performed for the construction validity. The Kaiser-Meyer-Olkin (KMO) value of the scale was found to be .897 . Bartlett's test was found to be significant $(p=<.01)$. In the EFA, when the five-factor structure of the scale was examined, despite explaining $67.8 \%$ of the variance, the eigenvalue of the 5 th factor was found to be less than 1 (.98) and there was only one item in the 5th factor. Additionally, the scree plot was examined and it was decided that the five-factor structure was not suited to the data.

The four-factor structure was then found to explain $62 \%$ of the variance. The four factors being Computer/ Internet Self-efficacy (three items, load values between .862 and .677), Self-directed Learning (five items, load values between .797 and .636), Learning Control (three items, load values between .802 and .478), and Motivation and Communication (seven items, load values between .76 and .55). The Cronbach Alpha reliability coefficient of the scale was calculated as .906, with coefficients for the sub-factors found to be .789 for Computer/Internet Self-efficacy, .816 for Self-directed Learning, .645 for Learning Control, and .870 for Motivation and Communication.

The factor structure of the scale was tested with Confirmatory Factor Analysis. CFA were performed using Lisrel. For the construct validity, compliance statistics were calculated for the four-factor model from the aforementioned EFA. The factor weights of the substances ranged from .42 (Item 10) to .82 (Items 2 and 7).

When the fit indices of the model tested with CFA were examined, it was seen that the chi-square value $\left(X_{2}\right.$ $=391.41, N=266, \mathrm{SD}=129, p=.00)$ was significant. However, as the sample expands, the likelihood of chi-square analysis results increases significantly. Therefore, $\mathrm{X}_{2} / S D$ ratio is recommended in large samples. Table 3 shows the statistics on the compliance of the CFA results of the scale.

\section{Attitudes of Students Towards e-Learning (ASL)}

The original scale was developed by Wilkinson, Roberts, and While (2010). A revised version was then created by Haznedar and Baran (2012), after adapting and rearranging items from other scales in the related literature. The scale consists of 20, five-point, Likert-type items.

Validity and reliability studies were conducted for the sample in the current study. The KMO value was found to be .948 and Bartlett's test was found to be significant $(p=<.01)$. In the EFA of the scale, a twofactorial structure was found and the variance ratio explained $62.17 \%$ of this structure. The first factor is named as 'Familiarity to e-Learning' (10 items, load values between .866 and .712), and the second factor is 'Escape from e-Learning' (10 items, load values between .758 and .520) on the original scale. Factors and items were found to have one-to-one correspondence with the original scale. The Cronbach Alpha reliability coefficient of the scale was calculated as .942, with coefficients for the sub-factors as .951 for e-Learning Familiarity and .901 for e-Learning Escape.

The factor structure of the scale was tested with CFA. Conformity statistics were calculated for the factor analysis of the construct validity and for the two-factor model, which was the same as in the original scale. The factor weights of the substances ranged from .49 (Item 12) to .90 (Item 16).

When the fit indices of the model tested with CFA were examined, it was seen that the chi-square value $\left(X_{2}\right.$ $=625.59, N=266, S D=169, p=.00$ ) was significant. The $\mathrm{X}_{2} / S D$ ratio was 2.35. Table 3 shows the statistics on the compliance of the CFA results of the scale. 
Table 3. Values Related to Goodness of Fit Indices of the Scale

\begin{tabular}{lllll}
\hline Fit Index Type & Observed Value & Acceptable Value & $\begin{array}{l}\text { LROL } \\
\text { Research } \\
\text { finding }\end{array}$ & $\begin{array}{l}\text { ASL } \\
\text { Research } \\
\text { finding }\end{array}$ \\
\hline$X_{2} / S D$ & $0 \leq X_{2} / S D \leq 2$ & 3.00 & 2.35 \\
$\mathrm{NFI}$ & $.95 \leq \mathrm{NFI} \leq 1$ & $2 \leq X_{2} / S D \leq 3$ & .93 & .96 \\
$\mathrm{NNFI}$ & $.97 \leq \mathrm{NNFI} \leq 1$ & $.90 \leq \mathrm{NFI} \leq .95$ & .95 & .97 \\
$\mathrm{CFI}$ & $.95 \leq \mathrm{NNFI} \leq .97$ & .95 & .98 \\
$\mathrm{GFI}$ & $.97 \leq \mathrm{CFI} \leq 1$ & $.95 \leq \mathrm{CFI} \leq .97$ & .86 & .85 \\
$\mathrm{AGFI}$ & $.95 \leq \mathrm{GFI} \leq 1$ & $.90 \leq \mathrm{GFI} \leq .95$ & .81 & .81 \\
SRMR & $.90 \leq \mathrm{AGFI} \leq 1$ & $85 \leq \mathrm{AGFI} \leq .90$ & .064 & .05 \\
RMSEA & $0<\mathrm{SRMR}<.05$ & $.05<\mathrm{SRMR}<.10$ & .088 & .10 \\
\hline
\end{tabular}

Schermelleh-Engel, Moosbrugger, and Muller, 2003

In the study, when the fit indices of different types of values were examined, it was determined that the observed values were mostly within acceptable value limits (see Table 3). GFI ranges from 0 to 1 and is influenced by sample size and gives more accurate values in large samples (Schumacker \& Lomax, 2004).

\section{Open-Ended Questions}

As a qualitative measure, a structured interview questionnaire form was created by the researchers. The final version of the questionnaire was achieved through consultation with experts in the field of Education and Assessment. The questions in the structured interview form are as follows:

1. What do you think about receiving the Computer Literacy course through distance education?

2. What are your favourite aspects of distance learning?

3. What are your least favourite aspects of distance learning?

4. What do you think about the timing and duration of the live classes?

5. What do you think about the Moodle interface and course materials?

6. What do you think about the suitability of the instructional design and preferences of learning method?

7. What are your recommendations for students learning computer literacy through distance education?

\section{Data Analysis}

For the quantitative data, frequencies and percentages were used to analyse the data, whilst a paired $t$-test was performed in order to determine whether or not there was any statistically significant difference on learners' readiness towards online learning or students' attitudes towards e-learning. Skewness and kurtosis values were computed in order to check the normality assumption. The skewness value was found to be between .09 and -.54 , and the kurtosis value was between .18 and -.86 in this study. Given that these values were in the range of -2 to +2 , it can be said that the distributions are considered normal (Tabachnick $\&$ Fidell, 2007). Moreover, the arithmetic mean, mode, and median values for all the factors show that the distributions do not depart from normal distribution (Table 4). After testing the assumptions, $t$-test analyses were conducted. 
Table 4. Descriptive statistics for the variables of the study

\begin{tabular}{|c|c|c|c|c|c|c|c|c|}
\hline & & & Mean & Median & Mode & $\begin{array}{c}\text { Std. } \\
\text { Deviation }\end{array}$ & Skewness & Kurtosis \\
\hline \multicolumn{9}{|c|}{ Pre-test } \\
\hline \multirow{8}{*}{$\begin{array}{l}\text { Readiness } \\
\text { for Online } \\
\text { Learning } \\
\text { Scale }\end{array}$} & \multirow{2}{*}{$\begin{array}{l}\text { Computer / Inter- } \\
\text { net Self-Efficacy } \\
\text { (F1) }\end{array}$} & Pre-test & 9.23 & 9.00 & 9.00 & 2.54 & .00 & -0.21 \\
\hline & & Post-test & 10.33 & 10.00 & 9.00 & 2.59 & -.36 & .18 \\
\hline & \multirow{2}{*}{$\begin{array}{l}\text { Self-directed } \\
\text { Learning (F2) }\end{array}$} & Post-test & 18.40 & 19.00 & 20.00 & 4.00 & -.54 & .08 \\
\hline & & Pre-test & 18.98 & 19.00 & 17.00 & 3.55 & -.40 & .13 \\
\hline & \multirow{2}{*}{$\begin{array}{l}\text { Student Control } \\
\text { (F3) }\end{array}$} & Post-test & 9.40 & 9.00 & 9.00 & 2.51 & -.06 & -.31 \\
\hline & & Pre-test & 9.61 & 9.00 & 9.00 & 2.63 & -.17 & -.23 \\
\hline & \multirow{2}{*}{$\begin{array}{l}\text { Motivation \& } \\
\text { communication } \\
\text { (F4) }\end{array}$} & Post-test & 25.59 & 26.00 & 21.00 & 5.69 & -.32 & -.20 \\
\hline & & Pre-test & 25.61 & 26.00 & 28.00 & 5.92 & -.35 & -.35 \\
\hline \multirow{4}{*}{$\begin{array}{l}\text { Attitude } \\
\text { scale for } \\
\text { e-learning }\end{array}$} & \multirow{2}{*}{$\begin{array}{l}\text { Familiarity to } \\
\text { e-learning (F1) }\end{array}$} & Post-test & 30.60 & 30.00 & 30.00 & 9.93 & .09 & -.65 \\
\hline & & Pre-test & 35.13 & 35.00 & 35.00 & 9.42 & -.51 & -.23 \\
\hline & \multirow{2}{*}{$\begin{array}{l}\text { Escape from } \\
\text { e-learning (F2) }\end{array}$} & Post-test & 31.94 & 31.00 & 30.00 & 11.58 & -.17 & -.86 \\
\hline & & Pre-test & 32.68 & 33.00 & 30.00 & 6.83 & -.34 & -.41 \\
\hline
\end{tabular}

$N=266, p<.05$

The qualitative data were analysed using content analysis. The data was prepared for analysis, and the themes defined based on the objectives of the study, the categories were identified and the coding process initiated. Each answer given for each question was read more than once. Data were then coded according to the categories and frequency tables created. Codes and categories were rearranged and classified until consensus was reached between the researchers. To ensure its quality and validity, the researchers carefully considered their clarity of thought process during the data analysis and interpretations. The coded answers were crosschecked along with the themes and codes to check that they adequately reflected the issue being investigated. To ensure the reliability of the codes generated in the data analysis process, some of the data were re-analysed by the same researcher after a period of ten months had elapsed. The percentage of internal consistency of the two coding processes was found to be .74 . This result can be considered evidential for the required level of reliability. Finally, in the presentation of the results, significant ideas and statements of some of the participants are shown as supporting quotations in order to illustrate the findings from the qualitative dataset.

\section{RESULTS}

\section{Quantitative Findings}

\section{Learners' Readiness towards Online Learning}

The pre-test was performed during the first phase of the study, and in the second phase the post-test was applied. In both the first and second phase, the Online Learning Readiness Scale was applied to the study group (Table 5). 
Table 5. Paired $t$-test of means for Online Learning Readiness Variables

\begin{tabular}{lllcccccc}
\hline Sub-factors & Measurement & $N$ & $\bar{x}$ & $S$ & $S D$ & $t$ & $p$ & $\eta^{2}$ \\
\hline \multirow{2}{*}{ F1 } & Pre-test & 266 & 9.23 & 2.54 & 265 & -6.99 & $.000^{*}$ & -.43 \\
& Post-test & 266 & 10.33 & 2.59 & & & & \\
\hline \multirow{2}{*}{ F2 } & Pre-test & 266 & 18.40 & 4.00 & 265 & -2.40 & $.017^{*}$ & -.15 \\
& Post-test & 266 & 18.98 & 3.55 & & & & \\
\hline \multirow{2}{*}{ F3 } & Pre-test & 266 & 9.40 & 2.51 & 265 & -1.26 & .207 & -.08 \\
& Post-test & 266 & 9.61 & 2.63 & & & & \\
\hline \multirow{2}{*}{ F4 } & Pre-test & 266 & 25.58 & 5.69 & 265 & -0.57 & .954 & -.00 \\
& Post-test & 266 & 25.60 & 5.92 & & & & \\
\hline
\end{tabular}

According to the repeated measurement results to determine the effect of the applied experimental process, it was found that the final test scores of Computer/Internet Self-Efficacy $\left.\left(t_{265}\right)=-6.99, p>.05\right)$ and Selfguided Learning $\left.\left(t_{265}\right)=-2.40, p>.05\right)$ differed significantly from the pre-test scores. The mean of the students' pre-test scores for Computer/Internet Self-efficacy was found to be $\bar{x}=9.23$, whereas the mean of the post-test scores was $\bar{x}=10.33$. This finding indicates that the course taken with distance education had a significant effect on students' gaining Computer/Internet Self-efficacy.

Similarly, the mean of the pre-test of Self-directed Learning scores was found to be $\overline{\mathrm{x}}=18.40$, and $\overline{\mathrm{x}}=18.98$ for the post-test. Accordingly, it can be said that the course taken via distance education was effective in improving the self-directed learning skills of undergraduate students. Nevertheless, no significant difference was found between the pre-test and post-test scores obtained from repeated measures of Student Control, Motivation for Learning, and Online Communication Self-efficacy measures. In order to identify the effect size and the significance of the differences between the groups, eta square $\left(\eta^{2}\right)$ was examined (see Tables 4 and 5). According to Cohen (1988), if $\eta^{2}<.02$ it is grouped as small, and so in this case the effect sizes found can be said to be small.

\section{Attitudes of Students towards e-Learning}

The Attitude Scale for e-Learning was applied to the study group in the first and second phases of the study. Findings and interpretations of the Attitudes toward E-learning variables in both phases are presented in Table 6.

Table 6. Paired $t$-test of means for E-learning Attitude Variables

\begin{tabular}{llccccccc}
\hline Sub-factors & Measure & $N$ & $\bar{x}$ & $S$ & $S D$ & $t$ & $p$ & $\boldsymbol{\eta}^{\mathbf{2}}$ \\
\hline \multirow{2}{*}{ F1 } & Pre-test & 266 & 30.60 & 9.93 & 265 & -2.12 & .034 & -.13 \\
& Post-test & 266 & 31.94 & 11.58 & & & & \\
\hline \multirow{2}{*}{ F1 } & Pre-test & 266 & 35.13 & 9.42 & 265 & 4.43 & .000 &. $\mathbf{2 7}$ \\
& Post-test & 266 & 32.68 & 6.83 & & & & \\
\hline
\end{tabular}

There was a significant difference seen on the variables of e-Learning Familiarity $\left.\left(t_{265}\right)=-2.12, p>.05\right)$ and Escape from e-Learning $\left.\left(t_{265}\right)=4.43, p>.05\right)$ in the pre-test and post-test measures. The mean of the students' pre-test scores for Familiarity to e-Learning was $\bar{x}=30.60$, while the mean of the final test scores increased to $\bar{x}=31.94$. This finding indicates that the course taken through distance education had a significant effect on students' familiarity to e-learning. The mean of the pre-test scores of the students' Escape from e-Learning was $\bar{x}=35.13$, while the mean of the post test scores decreased to $\bar{x}=32.68$. Accordingly, it can be said that the course was effective in decreasing the students' escape attitudes from e-learning. 


\section{Qualitative Findings}

\section{Views about Receiving the Computer Literacy Course through Distance Education}

The majority of respondents $(n=94)$ to this question expressed their satisfaction about taking the course through the distance education medium. The reasons stated were that they found the distance learning method educational, efficient, useful, and appropriate for the course. Furthermore, they were able to find time for other courses and tasks $(n=7)$. In addition to these views, there were also students who were undecided between distance education and face-to-face education $(n=10)$, while students who thought negatively about distance education method $(n=41)$ did not find the method suitable, useful, or effective for them. Overall, the majority of the students were satisfied in taking the course via distance learning and it was revealed that they benefited from this medium of education.

The following are some of the thoughts mentioned by the students:

- 'It is comfortable for me and easy to learn thanks to [video recordings]'.

- 'Distance teaching is very comfortable, but face-to-face would be better. Because; we can go in anytime we want and I have always delayed entering because I usually sleep at the class time'.

- 'It is much better for students like me, as a hearing-impaired student. I think the other lessons should be face-to-face and at some time through distance education'.

- 'Distance learning method is very useful because when you cannot attend the live classes, you can still reach that information'.

\section{Views About Most Favoured Aspects of Distance Learning}

The benefits and opportunities provided by distance education was reported by 83 of the participants as the most favourable aspects, and included good communication with the lecturer, attending classes online from any location, and no loss of time in attending on-campus classes. One student expressed his consideration in terms of flexibility and comfort as, 'I like to listen to the lessons in the home environment, and it is easier to adjust the time according to your own speed'.

The second important theme, according to 65 of the participants, was the educational materials and their accessibility. The most favoured aspect was the recording of live courses that they did not attend. With regards to this topic, one student explained that 'There is no such thing as a missed class. It's a good thing for a student to be able to watch it later'. They also emphasised that other materials are always accessible via Moodle. Detailed views and the assigned codes are presented in Table 7.

Table 7. Views about most favoured aspects of distance learning

\begin{tabular}{lc}
\hline Most favoured aspects of distance learning & Number of indices \\
\hline Benefits and opportunities provided by distance education & 83 \\
Good communication with the lecturer & 26 \\
Attend classes online from any location & 23 \\
No loss of time attending classes on campus & 13 \\
Class duration and lectures & 7 \\
No obligation to join the live class & 6 \\
More convenient method than face-to-face & 5 \\
Using technology & 3 \\
Accessibility and course materials & 65 \\
Recording of live broadcasts & 29 \\
Access to information whenever wanted & 19 \\
Course materials & 13 \\
Assignments clear and easily accessible & 4 \\
\hline
\end{tabular}


The aspects that students liked in terms of distance education were in fact the main features of distance education. In particular, the availability of trainers and mobility in distance education means that this process was adequately supported.

\section{Views about Least Favoured Aspects of Distance Learning}

When looking at the least favoured aspects of distance education, the majority of participants stated that they did not find any unfavourable aspect of distance learning $(n=51)$. When the problems that were mentioned are examined, participants indicated that the schedule did not suit them $(n=27)$, that the distance education method did not suit them $(n=21)$, they experienced technical issues $(n=11)$, that they could not concentrate $(n=11)$, they found the assignments too challenging $(n=8)$, and they experienced problems with communication $(n=7)$. One student stated that distance education was inappropriate as, 'The lecture was good, but I was bothered by having to look at the computer for about an hour'. With regards to this topic, another student stated that, 'After about 14 years of face-to-face education, I took a course as distance education for the first time. I was unfamiliar with this method and experienced an indifference towards the course'. Regarding of topic of challenging homework, one student stated that, 'Especially, the last two homework assignments were overly difficult, so I think it should be made easier'. Many of the issues found less favourable could be addressed. It would also be possible to facilitate the adoption of distance education by increasing the readiness of the students.

\section{Views about Timing and Duration of Live Classes}

Students were asked to provide feedback on the day, time, and duration of the lectures. The majority of participants $(n=97)$ indicated that the schedule for the live classes was deemed appropriate. As well as those who indicated that the start time of the live lesson was too early or too late $(n=28)$, there were others $(n$ $=16$ ) who stated that the start times should have been changed. One student expressed an opinion on the late start time of classes as, 'It is not good having the course at home at night; it would be better if it was at school'. Another student stated that, 'As we were unaccustomed to having a class at that time, we were not used to it and it's hard to adapt [to this time]'. Finally, there were some students $(n=6)$ who stated that the length of the live class was a little long.

\section{Views about the Moodle Interface and Course Materials}

The students were asked about the learning management system (LMS) through which they connected to the distance education system, and about the materials available on the LMS, which is essentially the backbone of the distance course. It was seen that the majority of students $(n=121)$ favoured the LMS (Moodle) and found it to be good, successful, practical, and useful. With regards to the use of Moodle, one student said that 'The interface is very simple, and it is very easy to access resources and assignments', whilst another student expressed that 'The Moodle system is easy to use and uploading homework is easy, it takes a short time', and one stated that 'I found it very easy to find what I search for on the [Moodle] website; it was very useful. I also had the opportunity to evaluate myself with the homework'. However, a few of the students $(n=11)$ said that Moodle was slow and not useful.

Students were asked about the teaching materials, and whether or not they were considered to be aligned with the learning course objectives. Except for a few students $(n=26)$, the majority $(n=134)$ stated that the teaching materials were aligned with the learning objectives. With regards to the teaching materials, one student stated that they 'Help you to re-examine and are useful for computer-related practical exams', whilst another stated that 'It was especially useful to watch the live class recording again', and another said 'It was useful for me to reinforce what I had learnt'.

About the alignment of the examples, evaluation questions, and activities within the content; except for just a few students $(n=13)$, the majority $(n=134)$ found the examples, evaluation questions, and activities were aligned accordingly with the course content. As for the course homework and evaluation questions, a few of the students $(n=8)$ found them to be challenging. 


\section{Views about Suitability of Instructional Design and Learning Method Preference}

Most of the students $(n=105)$ stated that the instructional design of the course was suitable, whilst 47 stated it was not suited to them. Some of the opinions expressed were:

- 'It was absolutely suitable; especially for students with disabilities'.

- 'I am more disciplined and more involved in face-to face instruction'.

- 'I like to make eye contact with my instructor so that I can understand better'.

- 'No, because it is easier to interact with classroom teachers in face-to-face education and to socialise in class'.

When the students' preferences were sought in terms of learning method, 91 of the students preferred face-to-face instruction and 46 preferred distance education. Moreover, 17 of the students preferred both instructional methods. Some of the students expressed the following:

- 'I would prefer distance education, because I am more comfortable with distance education than face-to-face lessons as I'm hearing impaired. I'm stressed when not being able to hear the instructor; in short, it is difficult for me being in face-to-face education'.

- 'Distance education is suitable for its timing and for learning; whereas face-to-face lessons are convenient for better communication with the teacher'.

- 'Both have positive sides. Regarding learning, I would prefer face-to-face; however, I would prefer distance education because of time-saving'.

When the students were asked whether or not they would opt to take other courses through distance education, different thoughts emerged. A total of 108 students did not want to take any other distance course, and stated that not all courses are appropriate for distance education. However, 48 of the students stated that they did want to take other courses in the format of distance education, and mentioned they wanted online courses for Turkish Language and Literature, History of Revolution, English, Mathematics, Computer, and General Culture. About this topic, one student stated his feeling as 'English. Because it is easier to learn such lessons in the virtual environment and it does not affect other courses', whilst another said that 'Yes I would like to take. I think it would be best for English courses; because many countries learn foreign languages in this way. There are also very useful applications for learning foreign languages on the Internet'.

\section{Recommendations for Students to Learn Computer Literacy Lessons via Distance Education}

Students were asked for their recommendations as to how students could be most successful on the Computer Literacy course delivered via distance education. Most of the students $(n=68)$ recommended participating in live lessons regularly or to watch their recordings. Other recommendations were about repetition of lessons $(n=16)$, practicing what was told in the lessons $(n=15)$, doing homework $(n=14)$, solving selfevaluation questions $(n=13)$, and reviewing materials available on the LMS $(n=11)$.

With regards to regular class attendance, one student stated, 'I recommend attending each live lesson or following the recordings if you do not attend'. As to focusing on the live classes, one student stated that 'They should not be distracted by looking at other websites on the computer'. Lastly, one student suggested 'To send a message if they did not understand, to keep communication open by sending emails, to send evaluations by questionnaire, to pay attention to the assignments, and to ensure attendance without absenteeism'.

\section{DISCUSSION AND CONCLUSION}

In order to investigate the quantitative data of this study on the readiness and attitudes of 266 students taking distance education with e-learning, a normality test of the data was first performed. The paired $t$-test was used as a parametric test. The course was delivered through distance education and was found to have a significant effect on the students' gaining of Computer and Internet Self-Efficacy, and was effective in improving the Self-directed Learning Skills of the undergraduate students. In considering this result, it should be taken into account that it is natural that students improve their computer and Internet usage 
skills in distance education, and that they are taught about these subjects within the scope of a Computer Literacy course. Similarly, Topal (2016) observed a positive significant correlation between students' levels of satisfaction and readiness. Additionally, the motivation of students who directed their own learning process was found to be high and more positively influenced. According to Demir's (2015) study, results showed that self-directed learning was the most critical variable of achievement in online learning. Regarding selfdirected learning, Kirmizi (2015) stated that online learners plan their study and have high expectations for their learning. Horzum et al. (2015) determined that readiness levels of students directly affects the motivation of learners, and indirectly affects their perceived learning. As a result, the experiences gained and the training related to distance education affected the level of readiness for e-learning (Ozturk et al., 2018; Sharma, Gulsecen, Ozen, \& Kartal, 2015).

Moreover, the current study's course, which was delivered through distance education, had a significant effect on students' familiarity to e-learning. In addition to this, the course was considered effective in decreasing escape attitudes from e-learning. This may be due to both the course content and the method of teaching. The continual motivation of students in course lessons may be as a result of motivating students to attend and, most importantly, supporting their learning skills. Continuous communication with students and providing numerous resources may also support this end result. Similarly, Topal (2016) suggested increasing the satisfaction level of students by expanding the number and quality of materials utilised in online education; by providing more interaction; and by leveraging the power of new technological capabilities. The increase in e-learning attitudes of students actively participating in e-learning applications is in agreement with the studies of Aixia and Wang (2011), Cobanoglu, Uzunboylar, and Altun (2017), Rhema and Miliszewska (2014), and Zhu (2012).

According to the views ascertained in the current study about receiving a computer literacy course through distance education, the students expressed their satisfaction with taking the course through the distance education method; stating that they found distance learning as educational, efficient, useful, and appropriate for the course. As a result, they were afforded adequate time for other courses and tasks. Likewise, Harrington and Loffredo (2010) stated that students favour online education because the type of learning method is more suited to them, makes them use technology, and gives them the opportunity to be innovative. Fortune, Spielman, and Pangelinan (2011) stated that students preferred online learning with similar motivations when compared to on-campus students.

According to the students' views in the current study about their most favoured aspects of distance education, they listed communication with the teacher, participation in lessons from any desired place and at any time, and course materials and their accessibility. Similarly, Queiros and de Villiers (2016) examined students' views regarding online learning. Their findings showed special vital links among social presence (focusing on the interaction among people); technological aspects (access to and use of technology), and the utilisation of tools.

On the views about the students' least favoured aspects of distance learning, the majority of the participants stated that they did not find any particular aspect of their distance learning unfavourable. Where problems were mentioned, they indicated that the schedule did not suit them, that the distance education method did not suit them, they experienced technical issues, could not concentrate, found the assignments too challenging, or experienced communication problems. The majority of participants indicated that the schedule for live classes was found to be appropriate. As well as those who indicated that the start of the live lesson was either too early or too late, some stated that the start time should have been changed. Problems experienced in distance education could be seen as normal as the students were not considered that technically competent. If they were thought to be weak at the beginning of the course in terms of their readiness for e-learning, it could be considered that they should have reached a certain level by the end of the course. Communication problems are often one of the issues attributed to distance education. In order to resolve this, lecturers must be sure to reach out to all of their students. If teachers are constantly at the centre of the class/communication, such problems may well arise. Referring to this, Sonwalkar (2009) argued that online education has a tendency to be instructor-dominated, with only limited student interaction. It is therefore necessary to pay attention to the formation of an adequately shared learning environment. 
In the current study, the students were asked about the LMS they used (Moodle), through which they connected to the distance education system, and about the materials available on Moodle, which are the essential backbone for such a distance education course. It was seen that the majority of the students favoured the Moodle LMS, and reported that it was good, successful, practical, and useful. Students were asked about whether or not the teaching materials were aligned with the learning objectives; except for a few students, the majority stated that the teaching materials were aligned with the learning objectives. With regards to the alignment of the examples, evaluation questions, and activities with content, except for a very few students, the majority found them aligned accordingly with the content. As for the course homework and evaluation questions, a few of the students found them challenging. In a study by Sun and Chen (2016), the researchers emphasised efficient approaches for improving institutional success in transitioning to teach online effectively. They advised to give importance to well-structured courses, competent and motivated instructors, interaction between instructors and learners, forming an online learning community, and to ensure benefit is gained from appropriate technology utilisation.

Most of the students in the current study stated that the instructional design of the course was suitable, whilst other students stated it was not suited to them. When their preferences were asked in terms of the learning method, most of the students preferred face-to-face instruction, whilst some students preferred distance education, and a few preferred both. When they were asked whether or not they would like to take other courses through distance education, different thoughts emerged. Some of the students did not want to take any distance courses, stating that not all courses were appropriate for distance education; and some students wanted to take other courses via distance learning, mentioning courses such as Turkish Language and Literature, History of Revolution, English, Mathematics, Computing, and General Culture online. Students' preferences varied for distance learning. The remote nature of the course undertaken, the content, the method itself, their personal characteristics, and the quality of the teacher can all be influential in their choice. For the course in the current study, the students preferred both face-to-face and distance education.

In order to achieve success at the computer literacy course, the students in the current study recommended that future students participate in live lessons regularly or watch their recordings, to repeat the lessons, practice what was taught in the lessons, to do the homework, solve self-evaluation questions, and review materials available on the LMS. In order to finish a course, Capra (2011) recommended that the more an online teacher communicates and is accessible, the more obvious it is that the learner will be successful in their online classes.

The results of the current study, which were based on the opinions and attitudes of distance education students, may also instigate future research studies. The current research was limited to scales measuring readiness and attitude for e-learning, as well as open-ended questions. The study was conducted around an undergraduate Computer Literacy course and was therefore limited to the digital content of that course. The work was also limited by the teaching method applied. Students also had certain limitations because they took the course weekly for one hour online, and their lesson content was structured according to their own choice. Similar research could be designed to incorporate other student groups and other courses. In other courses given through distance education, the effect of other methods on student success and performance could be investigated by utilising different measurement tools. 


\section{BIODATA and CONTACT ADDRESSES of AUTHORS}

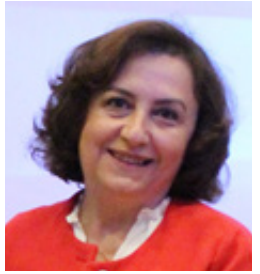

Dr. Emine CABI, is an Assistant Professor of Computer Education and Instructional at Education Faculty, Baskent University. Dr. Cabi gained her Ph.D. in Educational Technology at July, 2009. Her academic interest areas are distance learning, e-learning, instructional design, message design and use of technology in education. She has journal articles published in international indexes, book chapters and other national and international articles, papers submitted to international meetings.

Emine CABI

Address: Computer Education and Instructional, Education Faculty

Baskent University, 06790 Ankara, Turkey

Phone: +90 3122466616 / 2241

E-mail: eminec@baskent.edu.tr

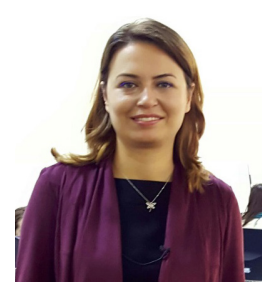

Dr. Filiz KALELIOGLU is an Associate Professor of Computer Education and Instructional at Education Faculty, Baskent University. Dr. Kalelioglu gained her Ph.D. in Educational Technology at July, 2011. Her academic interest areas are distance learning, e-learning, instructional design, use of technology in education and computer science education. She has journal articles published in international indexes, international book chapters and other national and international articles, papers submitted to international meetings.

Filiz KALELIOGLU

Address: Computer Education and Instructional, Education Faculty

Baskent University, 06790 Ankara, Turkey

Phone: +90 3122466619

E-mail: filizk@baskent.edu.tr

\section{REFERENCES}

Aixia, D., \& Wang, D. (2011). Factors influencing learner attitudes toward e-learning and development of e-learning environment based on the integrated e-learning platform. International Journal of e-Education, e-Business, e-Management and e-Learning, 1(3), 264-268.

Allport, G. W. (1935). Attitudes. In C. Murchison (Ed.), Handbook of Social Psychology (pp. 798-844). Worcester: Clark University Press.

Appatova, V., \& Prats, H. (2007, June). Effective academic environment for under-prepared collegeluniversity learners: listen to student voices. Paper presented at the 16th EAN Annual Conference Access to Success: The Student Experience from Pre-Entry to Employment, Galway, Ireland.

Arikan, Y. D. (2006). Web Destekli Etkin Ogrenme Uygulamalarinin Ogretmen Adaylarinin Derse Yonelik Tutumlari Uzerindeki Etkileri (The Effects Of Web-Supported Active Learning Activities On Teacher Trainees' Attitudes Towards Course). Ege Egitim Dergisi, 7(1), 23-41.

Capra, T. (2011). Online education: Promise and problems. Journal of Online Learning and Teaching, 7(2), 288-293.

Cobanoglu, A. A., Uzunboylar, O., \& Altun, E. (2017). Cevrimici Ogrenme Hazirbulunusluk, Tutum Ve Algilanan Cevrimici Sosyalligin Isbirlikli Harmanlanmis Bir Derste Incelenmesi (Investigating on-line learning readiness, attitudes and perceived on-line sociability in a collaborative blended course). Elektronik Sosyal Bilimler Dergisi, 16(63), 1218-1229.

Cole, M. T., Shelley, D. J., \& Swartz, L. B. (2014). Online instruction, e-learning, and student satisfaction: A three year study. The International Review of Research in Open and Distributed Learning, 15(6), 111-131. 
Creswell, J. W. (2012). Educational Research: Planning, Conducting, and Evaluating Quantitative and Qualitative Research (4th ed.). Boston: Pearson Education.

Demir, O. (2015). The investigation of e-learning readiness of students and faculty members: Hacettepe university faculty of education example (Unpublished Master's Thesis). Hacettepe University, Ankara.

Eagly, A. H., \& Chaiken, S. (1993). The psychology of attitudes. Harcourt Brace Jovanovich College Publishers.

Engin, M. (2017). Analysis of Students' Online Learning Readiness Based on Their Emotional Intelligence Level. Universal Journal of Educational Research, 5(12), 32-40.

ECDL Foundation. (2017). Base Modules. Retrieved from http://ecdl.org/about-ecdl/base-modules.

Fabac, R., Vidacek-Hains, V., \& Pazur, K. (2011). Attitudes of undergraduate students with regards to the information and communication aspects of study. In V. Luzar-Stiffler, I. Jarec, \& Z. Bekic (Eds.), Proceedings of the ITI 2011 33rd International Conference on Information Technology Interfaces (ITI) (pp. 263-268). IEEE.

Fishbein, M., \& Ajzen, I. (1977). Belief, attitude, intention, and behavior: An introduction to theory and research. Philosophy and Rhetoric, 10(2), 130-132.

Fortune, M. F., Spielman, M., \& Pangelinan, D. T. (2011). Students' Perceptions of Online or Face-to-Face Learning and Social Media in Hospitality. Journal of online learning and teaching, 7(1), 1-16.

Hao, Y. (2016). Middle school students' flipped learning readiness in foreign language classrooms: Exploring its relationship with personal characteristics and individual circumstances. Computers in Human Behavior, 59, 295-303.

Harrington, R., \& Loffredo, D. (2010). MBTI personality type and other factors that relate to preference for online versus face-to-face instruction. Internet and Higher Education, 13(1-2), 89-95.

Haznedar, O., \& Baran, B. (2012). Egitim Fakultesi ogrencileri icin e-ogrenmeye yonelik genel bir tutum olcegi gelistirme calismasi (Development of a general attitude scale towards e-learning for faculty of education students). Egitim Teknolojisi Kuram ve Uygulama, 2(2), 42-59.

Horzum, M. B., Kaymak, Z. D., \& Gungoren, O. C. (2015). Structural Equation Modeling towards Online Learning Readiness, Academic Motivations, and Perceived Learning. Educational Sciences: Theory and Practice, 15(3), 759-770.

Hung, M. L., Chou, C., Chen, C. H., \& Own, Z. Y. (2010). Learner readiness for online learning: Scale development and student perceptions. Computers \& Education, 55(3), 1080-1090.

Ilgaz, H., \& Gulbahar, Y. (2015). A snapshot of online learners: e-Readiness, e-Satisfaction and expectations. The International Review of Research in Open and Distributed Learning, 16(2), 171-187.

Jena, R. K. (2016). Investigating the interrelation between attitudes, learning readiness, and learning styles under virtual learning environment: a study among Indian students. Behaviour \& Information Technology, 35(11), 946-957.

Johnson, R. B., \& Onwuegbuzie, A. J. (2004). Mixed methods research: A research paradigm whose time has come. Educational researcher, 33(7), 14-26.

Kirmizi, O. (2015). The Influence of Learner Readiness on Student Satisfaction and Academic Achievement in an Online Program at Higher Education. Turkish Online Journal of Educational TechnologyTOJET, 14(1), 133-142.

Marchewka, J. T., Liu, C., \& Kostiwa, K. (2007). An application of the UTAUT model for understanding student perceptions using course management software. Communications of the IIMA, 7(2), 93-104.

Ozgur, H., \& Tosun, N. (2010, December). Internet destekli egitimin e-ogrenme tutumlarina etkisi (The effect of internet supported education on e-student attitudes). Paper presented at the XV. Turkiye'de Internet Konferansi, Istanbul Technical University. 
Ozturk, D. S., Ozturk, F., \& Ozen, R. (2018). The Relationship between Prospective Teachers' Readiness and Satisfactions about Web-Based Distance Education. Turkish Online Journal of Distance Education, 19(1), 147-162.

Parkes, M., Stein, S., \& Reading, C. (2015). Student preparedness for university e-learning environments. The Internet and Higher Education, 25, 1-10.

Queiros, D. R., \& de Villiers, M. R. (2016). Online learning in a South African higher education institution: Determining the right connections for the student. The International Review of Research in Open and Distributed Learning, 17(5), 165-185.

Rhema, A., \& Miliszewska, I. (2014). Analysis of student attitudes towards e-learning: The case of engineering students in Libya. Issues in Informing Science and Information Technology, 11, 169-190.

Sharma, S. K., Gulsecen, S., Ozen, Z., \& Kartal, E. (2015). Assessing E-learning Readiness of Instructors in Turkey. Istanbul Journal Of Innovation In Education, 1(3), 13-28.

Schermelleh-Engel, K., Moosbrugger, H., \& Muller, H. (2003). Evaluating the fit of structural equation models: tests of significance and descriptive goodness-of-fit measures. Methods of Psychological Research-Online, 8(2), 23-74.

Schumacker R. E., \& Lomax, R. G. (2004). A Beginner's Guide to Structural Equation Modeling, New York, NY: Routledge Academic.

Sonwalkar, N. (2009). The paradigm shift for adult education: from educational slavery to learning freedom of human brain with synaptic learning. In T. Kidd (Ed.), Online education and adult learning: New frontiers for teaching practices (pp. 151-163). Hershey, PA: IGI Global.

Sun, A., \& Chen, X. (2016). Online Education and Its Effective Practice: A Research Review. Journal of Information Technology Education, 15, 157-190.

Tabachnick, B. G., \& Fidell, L. S. (2007). Using multivariate statistics. Allyn \& Bacon/Pearson Education.

Tekinarslan, E. (2009). Turkish university students' perceptions of the World Wide Web as a learning tool: An investigation based on gender, socio-economic background, and web experience. The International Review of Research in Open and Distributed Learning, 10(2).

Topal, A. D. (2016). Examination of University Students' Level of Satisfaction and Readiness for E-Courses and the Relationship between Them. European Journal of Contemporary Education, 15(1), 7-23.

Venkatesh, V., Morris, M. G., Davis, G. B., \& Davis, F. D. (2003). User acceptance of information technology: Toward a unified view. MIS Quarterly, 27(3), 425-478.

Venkatesh, V., Thong, J. Y., \& Xu, X. (2016). Unified theory of acceptance and use of technology: A synthesis and the road ahead. Journal of the Association for Information Systems, 17(5), 328-376.

Wilkinson, A., Roberts, J., \& While, A. E. (2010). Construction of an instrument to measure student information and communication technology skills, experience and attitudes to e-learning. Computers in Human Behavior, 26(6), 1369-1376.

Yoo, S. J., Han, S. H., \& Huang, W. H. (2012). The roles of intrinsic motivators and extrinsic motivators in promoting e-Learning in the workplace: A case from South Korea. Computers in Human Behavior, 28(3), 942-950.

Yurdugul, H., \& Alsancak Sarikaya, D. (2013). The scale of online learning readiness: A study of validity and reliability. Egitim ve Bilim, 38(169), 391-406.

Zabadi, A. M., \& Al-Alawi, A. H. (2016). University Students' Attitudes towards E-Learning: University of Business \& Technology (UBT)-Saudi Arabia-Jeddah: A Case Study. International Journal of Business and Management, 11(6), 286-295.

Zhu, C. (2012). Student satisfaction, performance, and knowledge construction in online collaborative learning. Journal of Educational Technology \& Society, 15(1), 127-136. 